\section{Finding Jobs: \\ Placement of Political Scientists, 1987}

\author{
Sheilah Mann \\ American Political Science Association
}

\section{The Placement Class}

One hundred and three Ph.D. granting departments (86\%) responded to the survey about the 1987 placement class. Of these, ninety departments ( $87 \%$ ) reported having job candidates. There is a considerable range in the size of each department's "placement class." The University of California, Berkeley had, by far, the most candidates for jobs: 51 or $8 \%$ of the 604 job candidates for 1987. The University of Michigan with 21 candidates had the second largest placement class and the University of Chicago, Yale University and the University of North Carolina complete the ranking for the five departments providding the most candidates for political science positions. Twenty-four departments reported having nine or more job candidates, accounting for $56 \%$ of the 1987 placement class. Forty-six departments had from five to eight candidates or $28 \%$ of the placement class. Thirty departments, who had four or fewer job candi- dates, trained $16 \%$ of the 1987 placement class.

\section{Placement Success}

The degree of success achieved by political science graduate students in finding jobs has been constant. Table I shows that, except for 1982, at least $70 \%$ of the candidates have found positions. Data from the 1970s showed similar success rates.

Table I also indicates what proportion of these placements were in temporary positions. The proportion of candidates taking temporary positions has ranged somewhat and reached $43 \%$ in 1985. But there is a decline, in the last two years, that bears watching. There is some evidence that the number of new jobs for political scientists is expanding, and this may account for the drop in temporary jobs. These prospects will be discussed later in the report.

Table 2 shows that the placement success for candidates with a Ph.D. remains higher than that for $A B D$ candidates, although $A B D$ s fared better on the latest survey than they had since 1984.

Table 3 shows placement by gender. In the last two years, women experienced greater overall placement success than men, and a smaller proportion of women than men took temporary jobs.

Table I. Trends in Placement*

\begin{tabular}{lrrrrrrr}
\hline & 1981 & 1982 & 1983 & 1984 & 1985 & 1986 & 1987 \\
\hline Number of firm candidates & 697 & 611 & 523 & 672 & 715 & 690 & 604 \\
\% repeats & 35 & 36 & 41 & 38 & 37 & 32 & 36 \\
Placement success of firm candidates & 73 & 62 & 79 & 72 & 70 & 69 & 72 \\
(\%) & 28 & 36 & 33 & 24 & 43 & 38 & 27 \\
\% of placement in temporary positions & 28 & 64 & 65 & 64 & 69 & 69 & 76 \\
$\%$ placement of Ph.D.s & 81 & 72 & 87 & 77 & 81 & 83 & 80 \\
Placement success of Ph.D.s (\%) & 18 & 19 & 19 & 18 & 17 & 9 & 9 \\
\% of placement in nonacademic jobs & & & &
\end{tabular}

*Figures are estimates of total population based on samples of 97 departments for 1980 (79\% response rate), 94 departments in 1981 (76\% response rate), 91 departments for $1982(76 \%$ response rate), 87 departments in 1983 (73\% response rate), 83 departments for 1984 (71\% response rate), 82 departments in 1985 (68\% response rate), 83 departments for 1986 (70\% response rate), and 103 departments for 1987 ( $86 \%$ response rate). 
Table 2. Degree Completion and Placement Success, 1983-87 (\%)

\begin{tabular}{cccc}
\hline & \multicolumn{3}{c}{ Placement Success* } \\
\cline { 2 - 4 } & Total & Men & Women \\
\hline ABD & & & \\
1983 & 54 & 53 & 57 \\
1984 & 68 & 64 & 83 \\
1985 & 51 & 52 & 50 \\
1986 & 57 & 56 & 62 \\
1987 & 68 & 67 & 68 \\
Ph.D. & & & \\
1983 & 87 & 87 & 88 \\
1984 & 77 & 80 & 69 \\
1985 & 81 & 78 & 90 \\
1986 & 83 & 81 & 88 \\
1987 & 80 & 77 & 87 \\
\hline
\end{tabular}

* Placement success measures number placed within each category as a percentage of the total candidates within each category.

In 1987, there were only twenty-three black job candidates and five Spanish surnamed candidates. Fifteen of the black candidates $(65 \%)$ were placed, and all of the Spanish surnamed candidates were placed. Among the black candidates with Ph.D.s only seven $(58 \%)$ were placed. The placement success for black candidates, in general and especially for black Ph.D.s, is lower than that for whites, a troubling finding since many departments are trying to recruit black faculty.

Placement success by field is reported in Table 4. Over the years, placement success has varied by field and continues to do so. Overall, the placement success of candidates in American government and that of candidates in the "associated" American fields of public policy and public administration continues to be high. The placement success of candidates in political theory is lower than it was in 1986. On the other hand, there are encouraging signs for the "non-Americanists": the placement success of candidates specializing in comparative politics/area studies and in international relations was higher for the 1987 class than the previous two classes, although it has been as high in some prior years. There are very few candidates identified as specializing in "methodology" or in some "other" field, 3 and 4, respective $l y$, in the last survey, so that their placement success is either due to the dearth of these specialists or the skills of these particular candidates.

Table 4 also indicates what percentage of the overall placements are accounted for by candidates in the different fields There is an upward trend in the propor. tion of placements accounted for by candidates specializing in comparative politics/ area studies and in international relations There has been a very small, but consistent decline in the share of jobs claimed by candidates in American government, public policy and public administration.

Differences in placement success between men and women varied somewhat by field in 1987 as in previous years

Table 3. Placement of Job Candidates by Sex, 1983-87

\begin{tabular}{lccc}
\hline & Total $^{*}$ & Men & Women \\
\hline $\begin{array}{l}\text { Number of Firm } \\
\text { Candidates }\end{array}$ & & & \\
1983 & 523 & 390 & 133 \\
1984 & 672 & 504 & 168 \\
1985 & 715 & 522 & 193 \\
1986 & 690 & 510 & 180 \\
1987 & 604 & 438 & 166 \\
Number Placed & & & \\
1983 & 414 & 326 & 88 \\
1984 & 485 & 365 & 119 \\
1985 & 497 & 363 & 134 \\
1986 & 477 & 344 & 133 \\
1987 & 455 & 328 & 127 \\
Placement & & & \\
Success (\%) & & & \\
1983 & 79 & 79 & 66 \\
1984 & 72 & 72 & 71 \\
1985 & 70 & 70 & 69 \\
1986 & 69 & 67 & 74 \\
1987 & 72 & 70 & 75 \\
Percent in & & & \\
Temporary & & & \\
Positions (\%) & & & \\
1983 & 33 & 32 & 39 \\
1984 & 33 & 33 & 34 \\
1985 & 43 & 43 & 43 \\
1986 & 38 & 40 & 35 \\
1987 & 27 & 29 & 24 \\
\hline "Ad & & & \\
\hline
\end{tabular}

${ }^{*}$ Adjusted total 


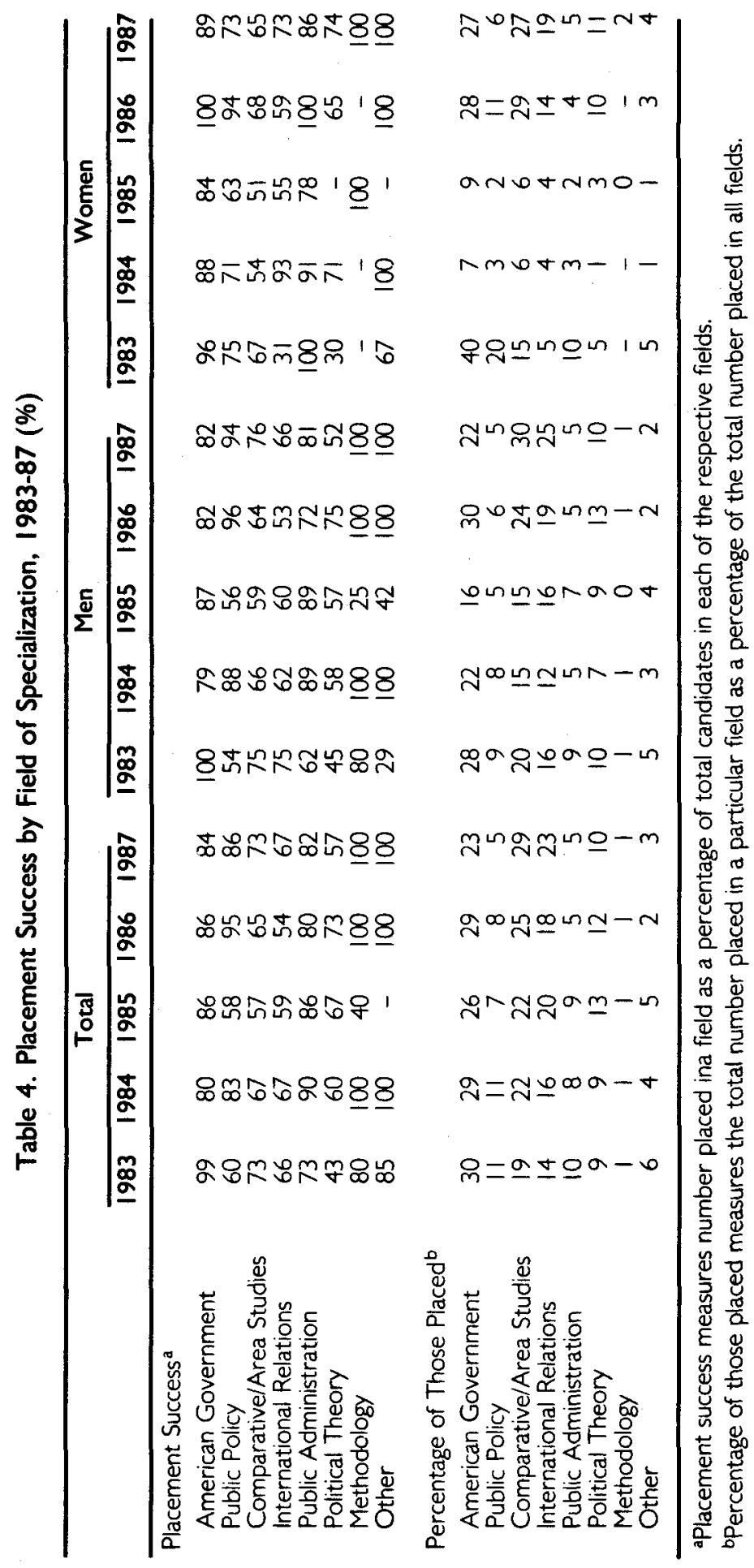


Women have had somewhat greater success than men in American government since 1983. In 1987, in addition to American Government, a greater proportion of women than men were placed in international relations, public administration and political theory. In other fields, there is no consistent pattern in placement success by gender. In 1987, public policy and comparative politics were the only fields in which a difference in placement success of $5 \%$ or more favored men

Departments reported on plans for their job candidates who were not placed The largest proportion of these candidates, $42 \%$, were able to remain at their universities with financial support. Another $18 \%$ planned to remain at their universities without financial support. The status of little more than one-fifth, or $22 \%$ of the candidates, was considered uncertain and $12 \%$ were unemployed. The lowest proportion, under $1 \%$, accepted employment outside the profession.

Table 5 shows that Ph.D. departments continue to claim the largest share of job candidates. All graduate departments, Ph.D. and M.A. combined, accounted for $56 \%$ of the placements. Since 1983 graduate departments have hired from $52 \%$ to $57 \%$ - a stable majority share-of political scientists seeking employment. The proportion of political scientists employed by undergraduate departments, which account for the next largest share of placements, has also remained relatively stable, ranging from a low of $23 \%$ in 1985 to a high of $29 \%$ in 1987 . Undergraduate social science departments and two-year colleges continue to hire a very small proportion of job candidates, ranging from $2 \%$ to $5 \%$ each year in the last five years. Finally, the proportion of candidates hired by nonacademic organizations declined continually from 1982 to 1986 , from $24 \%$ to $9 \%$, and rose only slightly to $12 \%$ in 1987 . When departments were asked whether they anticipated an increase in nonacademic employment in the coming year, $74 \%$ did not, only $3 \%$ did and $13 \%$ were not sure.

\section{Future Employment Prospects}

It appears that political science will remain primarily an academic profession. There is reason for optimism about placement of political science graduate students in academia. Ours appears to be a healthy discipline, both in terms of its appeal to undergraduate students and an increase in positions. Political science is benefiting from a current and anticipated increase in undergraduate student enrollments and faculty size.

A survey of incoming college freshmen, for 1988-89, reports that political science has a far larger share of likely majors, $3.2 \%$, than any other major discipline in the arts and humanities. In the social sciences, only psychology was selected by more freshmen (4.1\%). History, sociology, economics and anthropology were the intended majors, respectively, of . $8 \%, .9 \%$, $.5 \%$ and $.2 \%$ of the freshmen (Chronicle, 1989).

Responses to the Association's Annual Departmental Survey indicate there is some expansion in student enrollments and in degrees awarded in political science, in the most recent years, and particularly for the 1986-87 academic year. Table 6 summarizes these data.

It is likely that political science enrollments mirror an increase in undergraduate enrollments in many institutions. The majority of colleges and universities (54\%) have experienced net increases in enrollment since 1980 and continue to be optimistic about enrollment despite lower numbers of high school graduates anticipated from 1989 to 1994. The American Council on Education reports that, "Fully 7 in 10 administrators expect enrollment increases for their institutions over the next five years." Only $16 \%$ of the administrators anticipate a decrease in enrollment (El-Khawas, 1988, p. vi).

Responses to questions in the Association's Survey of Departments about hiring new faculty indicate that there is a recent increase in political science positions. Table 7 presents these data. 


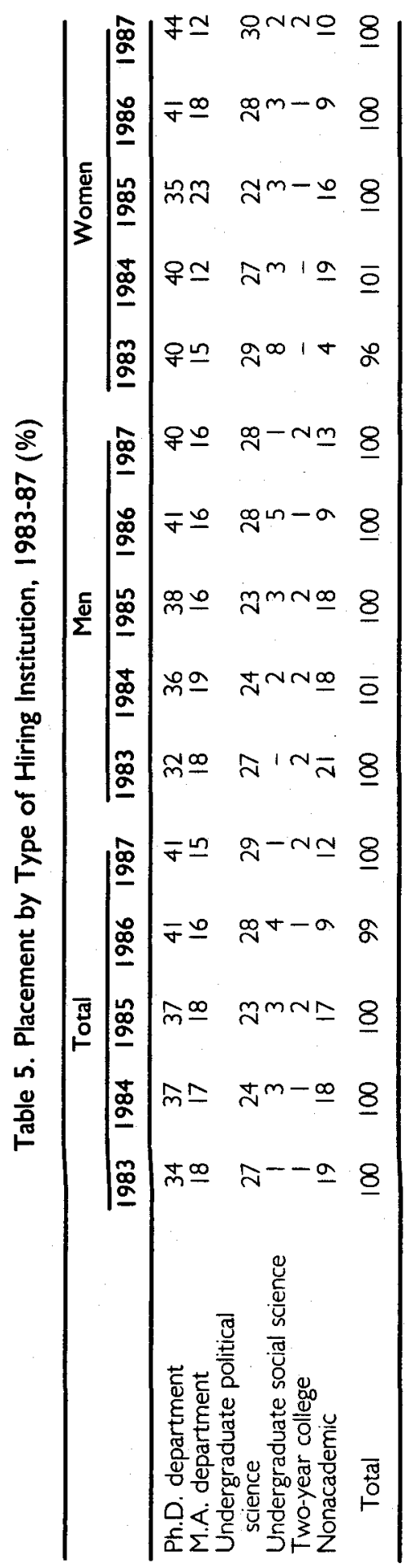


Table 6. Undergraduate Enrollments and Degrees Awarded, $1982-87^{*}(\%)$

\begin{tabular}{lccccc}
\hline & $1982-83$ & $1983-84$ & $1984-85$ & $1985-86$ & $1986-87$ \\
\hline $\begin{array}{l}\text { Change in Total Political } \\
\text { Science Enrollment }\end{array}$ & & & & & \\
$\quad \begin{array}{l}\text { Increase } \\
\text { No Change }\end{array}$ & 37 & 42 & 41 & 41 & 54 \\
$\quad$ Decrease & 37 & 36 & 33 & 57 & 31 \\
Change in Political Science & 26 & 22 & 26 & 22 & 15 \\
Degrees Awarded. & & & & & \\
$\quad$ Increase & 35 & 35 & 34 & 36 & 41 \\
$\quad$ No Change & 41 & 45 & 44 & 44 & 41 \\
Decrease & 24 & 20 & 21 & 20 & 18 \\
\hline
\end{tabular}

*These are data from one academic year to the next and the dates represent the end of an academic year, e.g., 1981-82 to 1982-83 is shown as 1982-83

Table 7. Faculty Hiring, 1983-88

\begin{tabular}{lccccc}
\hline & $1983-84$ & $1984-85$ & $1985-86$ & $1986-87$ & $1987-88$ \\
\hline $\begin{array}{l}\text { Change in Faculty Size (\%) } \\
\text { Net Gain }\end{array}$ & 12 & 12 & 16 & 16 & 20 \\
$\begin{array}{l}\text { Net Loss } \\
\text { No Change }\end{array}$ & 11 & 77 & 13 & 12 & 10 \\
$\begin{array}{l}\text { Number of Foculty Hired for } \\
\begin{array}{l}\text { New Positions } \\
\text { Number of Foculty Expected to }\end{array}\end{array}$ & 73 & 80 & 77 & 86 & 147 \\
$\begin{array}{l}\text { be Hired for New Positions } \\
\text { in the Coming Year: }\end{array}$ & 67 & 80 & 108 & 142 & 159 \\
\hline
\end{tabular}

The increase in faculty reported by political science departments is part of a general picture of expansion. The American Council on Education's report on Compus Trends notes that there has been a steady increase in the percentage of colleges reporting a gain in faculty positions over the last three years (El-Khawas, 1989, p. 6).

Another factor in the size of the job market is the replacement of faculty due to retirement. Past "Placement Reports" have indicated that political science is a relatively young profession and positions are not going to be available in considerable numbers due to retirements. A survey based upon the 1988 Biographical Directory finds that the median age of political scientists is 45.2 years, a finding which supports the predictions made in previous years. *

Political science is not unique in this regard. The American Council on Education reports relatively low college and university levels of faculty retirements, and this is not expected to change in the next five years (El-Khawas, 1989, pp. 7-8). Consequently, the growth in political science positions will need to continue to come from the creation of new positions.

Political science Ph.D. departments appear to be somewhat optimistic. Forty-one percent of the departments responding expected to have the same number of candidates seeking positions in the coming year. Thirty-seven percent of the departments anticipated a larger placement class. Only $8 \%$ of the departments said their next placement class would be smaller. If the current and 
anticipated expansion in political science departments continues, then the overall placement success of job candidates should remain the same, with a possible continued decline in the proportion of candidates accepting temporary jobs.

\section{Note}

\footnotetext{
*After 1987, one-half of the political scientists as well as doctoral scientists in general, were 45 years of age or older. National Foundation, Science Resource Studies Highlights. April 28, 1989, p. 2.
}

\section{References}

El-Khawas, Elaine. 1988. Campus Trends, 1988. Washington, D.C.: American Cuncil on Education.

"FACT File: Attitudes and Characteristics of This Year's Freshmen," The Chronicle of Higher Education, I I January 1989, p. A33.

\section{Research Grantees Announced}

The APSA Research Support Committee announced the 1989 Research Grantees on May I. The Council established the Research Grant program in 1984, and authorized $\$ 15,000$ to be distributed annually. To be eligible for a grant the applicants must be APSA members and must either be a faculty member at a non-Ph.D. granting college or university or be a political scientist not affiliated with an academic institution. Funds are used for research that addresses a significant problem in political science.

The Selection Committee, composed of Paul Hammond, University of Pittsburgh, chair; Donna Bahry, New York University; David Brady, Stanford University; Roy F. Grow, Carleton College; Carole Uhlaner, University of California, Irvine; and Howard Wiarda, University of Massachusetts, reviewed 41 applications and awarded 14 grants for 1989. The grantees are:

Constance G. Anthony, Seattle University, "The AIDS Regime: Hegemony, Technology, and African Assistance."

Christopher J. Bosso, Northeastern University, "Origins, Maintenance, and Policy Agenda of the National Coalition Against the Misuse of Pesticides."

William Paul Collins, Samford University, "Drawing District Boundaries: Describing the Legislative Process.'

Allan D. Cooper, Saint Augustine's College, "Supranational Monitoring of Electoral Campaigns: The Promise of U.N.T.A.G. in Namibia."

Raymond W. Cox III, New Mexico State University, "The Governor in the 1990s."

Iva Ellen Deutchman, Hobart and William Smith Colleges, "Women, Power, and Political Participation."

H. Richard Friman, Marquette University, "When Worlds Collide: The United States, Germany, Japan, and the International Drug Trade."

George Moyser, University of Vermont, "Political Participation and Liberal Democracy in Britain."

Shaheen Mozaffar, Bridgewater State College, "'The Colonial State and Transformation in Africa: A Case Study of Nigeria, 1885-1960."

Eric Plutzer, lowa State University, "The Process of Religious Influence."

James A. Regalado, California State University, Los Angeles, "At Large Election Systems in Southern California: Racial Segregation in Political Markets?'

Mark J. Rozell, Mary Washington College, "The Press and the Ford Presidency."

Carmine Scavo, East Carolina University, "The Impact of Participative Mechanisms on Out-Migration from Large American Cities."

Christopher E. Smith, University of Akron, "An Analysis of Reagan Era En Banc Decisions in the U.S. Court of Appeals." 